Revue Française de Civilisation Britannique

\title{
From Grunwick to Gate Gourmet: South Asian Women's Industrial Activism and the Role of Trade Unions
}

De Grunwick à Gate Gourmet : le militantisme des femmes sud-asiatiques et le rôle des syndicats

Sundari Anitha, Ruth Pearson and Linda McDowell

\section{OpenEdition}

\section{Journals}

Electronic version

URL: http://journals.openedition.org/rfcb/1790

DOI: $10.4000 /$ rfcb. 1790

ISSN: 2429-4373

\section{Publisher}

CRECIB - Centre de recherche et d'études en civilisation britannique

\section{Electronic reference}

Sundari Anitha, Ruth Pearson and Linda McDowell, «From Grunwick to Gate Gourmet: South Asian Women's Industrial Activism and the Role of Trade Unions », Revue Française de Civilisation Britannique [Online], XXIII-1 | 2018, Online since 20 March 2018, connection on 22 August 2020. URL : http:// journals.openedition.org/rfcb/1790; DOI : https://doi.org/10.4000/rfcb.1790

This text was automatically generated on 22 August 2020.

\section{cc) (1) $8 \odot$}

Revue française de civilisation britannique est mis à disposition selon les termes de la licence Creative Commons Attribution - Pas d'Utilisation Commerciale - Pas de Modification 4.0 International. 


\title{
From Grunwick to Gate Gourmet: South Asian Women's Industrial Activism and the Role of Trade Unions
}

\author{
De Grunwick à Gate Gourmet : le militantisme des femmes sud-asiatiques et le \\ rôle des syndicats
}

Sundari Anitha, Ruth Pearson and Linda McDowell

\section{Introduction}

1 The focus of this article is an analysis of the effectiveness of the trade union response to the participation of South Asian women workers in two industrial disputes: at the Grunwick photo-processing firm between 1976-78 and the Gate Gourmet food processing unit at Heathrow Airport in 2005. Both disputes involved first generation migrants to the UK, and both failed to achieve their aims, ending in discord between the strikers and their unions. The Grunwick dispute, which has since assumed an iconic status in British labour history, reflected the circumstances of the 1970s, a particular moment in British Labour history characterised by mass solidarity action during the heyday of industrial militancy. The Gate Gourmet dispute unfolded in a very different political, economic and regulatory framework for the trade unions, in an era of rapid industrial outsourcing and increasing precarity of the workforce. The research on which this article is based questions the on-going commitment of the British trade union movement to supporting migrant women workers while recognising that changes in industrial relations legislation, the normalisation of precarious employment contracts and the declining political power of trade unions have all contributed to weakening the room for manoeuvre of organised labour to effectively protect marginalised sections of the labour force. 


\section{Background}

The Grunwick strikers were predominantly Gujarati Hindus of East-African origin who had arrived in the UK between late 1960s and the early-1970s, largely from urban, English-language-educated and middle-class backgrounds. At the time of the Grunwick dispute they were mostly in their twenties and thirties. These workers have been described as "twice-migrants" 1 who prospered in Africa under the colonial rule by occupying an intermediary class position between the colonial rulers and the native population. ${ }^{2}$ Though all the Grunwick strikers had previous experience of paid work in either East Africa or India, in keeping with their class status this had been in "respectable" occupations such as teaching, secretarial work or home-based work. Following policies of Africanization, they migrated as entire family units and without a "myth of return", ${ }^{3}$ making a long-term commitment to settle indefinitely in the UK. This entailed women's entry into the labour market in the UK, and accepting the types of low-status and low paid factory work typically available to women migrants at that time.

3 The women workers who were sacked at Gate Gourmet were Punjabi - mostly Sikh and some Hindu - direct migrants who came to the UK between late 1960s to the early 1980 s from agrarian communities. At the time of the dispute in 2005, they were a relatively older workforce, in their fifties and sixties, living in the area around Southall, London, where Heathrow Airport was a major source of employment. Most of them had long working histories in the UK. They had responded to their employment in low paid, low status jobs by joining trade unions and had previous experience of industrial militancy in other workplaces such as Hillingdon hospital and Lufthansa Skychef as they struggled to evade managerial control and sought dignity, respect and better pay and conditions.

4 The research that we draw on here was carried out between 2007 and 2009, involving life-history interviews with five of the then-elderly Grunwick strikers, and 27 Punjabi women workers sacked by Gate Gourmet. Apart from the Grunwick strike leader, Jayaben Desai, the names of the women have been changed to protect their identity. Utilising life history methods enabled us to move away from an incident-centred analysis of the two industrial disputes to one where the research participants were able to reflect on their lives as a whole and enabled us to locate their working lives and their participation in the disputes in the context of their broader histories of migration and settlement, family and community relations and their current circumstances.

There is a large secondary literature on the Grunwick dispute as well as a range of political and journalistic accounts ${ }^{4}$ and video production including documentaries by Chris Thomas. We drew on these existing sources, undertook interviews with a number of key actors including members of the Grunwick strike committee and other strikers as well as drew upon archival sources including documents released under the 30-year Rule and Special Branch Files made publicly available over 2016-17. In contrast there are few published accounts of the Gate Gourmet dispute. In this case, in addition to the interviews with the workers, our research was informed by interviews with three senior officials in the TGWU (now UNITE), by direct observation of the proceedings of several cases that were heard at an Employment Tribunal in Reading, and by analysis of the full judgements of the 17 Employment tribunal cases heard between November 2006 and June 2008. These sources provide a unique perspective of the ways in which 
this group of South Asian women workers experienced the role of their trade union in the genesis, trajectory and official conclusion of their dispute.

Whereas the singular account of Jayaben Desai, the leader of the Grunwick dispute, had hitherto served to represent all the women strikers, we also interviewed four other women who participated in the strike. A principal objective of our research was to document the voices of a range of women involved, in a context where the ownership of the memory of the Grunwick dispute has been claimed by trade unions, particularly in the $30^{\text {th }}$ and $40^{\text {th }}$ anniversary years when celebrations marking it were held. ${ }^{5} \mathrm{In}$ contrast the Gate Gourmet dispute continues to be ignored by the mainstream media, and there is little appetite for the participants' alternative accounts of this dispute.

7 Focusing on these disputes enables us to explore the agency of two groups of South Asian women workers, to understand their engagement in mainstream trade union practices and render visible the experiences of women whose voices continue to be marginalised. We recount their stories of involvement in industrial militancy as a counterpoint to widely expressed surprise at South Asian women's presence on a picket line: a surprise that has persisted despite a long history of South Asian women's labour activism in the UK. ${ }^{6}$ These women's dissent continues to be represented through familiar orientalist constructions - both in mainstream media and some trade union accounts $^{7}$ - as exotic, impulsive and somehow unusual compared to the norm of the white male industrial worker.

\section{Minority ethnic women in the UK labour market}

In the period after the Grunwick dispute, women's participation rate in the labour market (as a percentage of women of working age) in the UK increased from $60 \%$ of working population in 1981 to $76 \%$ in $2001 .{ }^{8}$ However, occupational and vertical segregation in the labour market continued to restrict many women to part-time, lowpaid jobs primarily in the $5 \mathrm{Cs}$ sectors - caring, cleaning, cashiering, catering and clerical work. ${ }^{9}$ Particular aspects of gendered inequalities in the labour market that have been explored include the impact of marriage, child-bearing, life-stage, level of qualifications ${ }^{10}$ and ethnicity. ${ }^{11}$

9 However the employment patterns of women from diverse ethnic backgrounds in the UK have varied significantly. ${ }^{12}$ Labour Force Survey data for 1979 for example, just after the end of the Grunwick dispute, indicates that compared to $25 \%$ of the employed British-born white women who worked in manufacturing in 1979, the corresponding figures were $58 \%$ for Indian, $45 \%$ for African-Asian, $54 \%$ for Pakistani and $50 \%$ for Bangladeshi women..$^{13}$ This pattern of relegation to low-paid, low-status occupations, described as the "ethnic penalty" in employment, ${ }^{14}$ has continued across the years between the two disputes. Among Black African, Black Caribbean, Pakistani and Bangladeshi workers and Sikh women, who are most likely to be working in low-skilled jobs, almost one in 10 was working as a process, plant or machine operative in 2004, compared with approximately 3 percent of women in other groups. ${ }^{15}$ Such differences have been the focus of a small body of literature that addresses the implications of women's different origins and backgrounds for their labour market positions and experiences at work. ${ }^{16}$ There is also a small but growing body of literature on the labour market experiences of particular categories of women workers. ${ }^{17}$ 
10 Black and minority ethnic women's struggles against gender-based and racial discrimination and disadvantage in the labour market have been documented, including references to particular examples of industrial action ${ }^{18}$ with or without the support of their union. ${ }^{19}$ Parrenas has analysed the ways in which life experiences and locations in terms of class, ethnicity, race and family situation combine to shape the identity and subjectivity of migrant women. ${ }^{20}$ But these themes of intersectionality have been neglected in relation to migrant women's experiences in the workplace, particularly their industrial militancy. ${ }^{21}$ According to Brah, the issues that are central to an understanding of the nature and experience of South Asian women in the UK labour force include the history of colonialism and imperialism, the timing of migrations, the restructuring of the national and global economies, the changing structure of labour markets, state policies, racial discrimination in the labour market and the segmentation of labour markets by gender, class, age and ethnic background. ${ }^{22}$ In spite of the research on labour force participation and documented examples of their activism, myths persist of these women's assumed domestic orientation ${ }^{23}$ as well as a stereotypical assumption that minority ethnic women workers are difficult to unionise, ${ }^{24}$ paralleling the repeated media surprise at their presence on picket lines.

\section{Trade unions and issues of gender, race and ethnicity: changes and challenges}

11 Despite the long involvement of black and minority ethnic workers in working class organisations in Britain ${ }^{25}$ trade unions historically have failed to adequately address the needs of women and minority ethnic workers. This neglect has been attributed variously to the ambivalence or hostility of early trade unions towards tackling racism and discrimination at work, ${ }^{26}$ exclusion strategies against Black and women workers, ${ }^{27}$ reluctance to take on issues specifically affecting women members, ${ }^{28}$ and the unrepresentative nature of the union decision-making structures which were effectively dominated by white men: ${ }^{29}$ a charge that holds to this day.

Some of the practices of trade unions in the 1960s and early 1970s included collusion with management policies of paying differential wages based on gender and race, barring certain groups of workers from promotion or selective redundancy strategies. ${ }^{30}$ Such discriminatory practices were the basis of disputes at Mansfield Hosiery in Loughborough in 1972 and at Imperial Typewriters in Leicester in $1974,{ }^{31}$ where South Asian women workers organised against their employers as well their own unions, often with the support of community groups. During this period, strategies of separate organising were explored in the context of the trade unions' neglect of issues of gender and the lack of representation of women in the union decision-making structures and practices in the UK. ${ }^{32}$ An initial trade union position that special policies to address the needs of black workers would discriminate against white union members gave way from the 1980s to the recognition of racial discrimination as an issue that required specific action, although measures such as positive action to tackle discrimination took somewhat longer to materialise. ${ }^{33}$

13 Since the 1990s, trade unions have taken a more engaged approach to questions of race and gender, ${ }^{34}$ though they have encountered new problems in reaching out to recent migrants who often work in low paid and precarious jobs where unions have little influence. This "ethnic division of labour" 35 poses new challenges to trade unions' 
capacity to represent the most vulnerable sections of the workforce. More recent research documents efforts by unions to organise beyond traditional structures and alliances, ${ }^{36}$ in what has been termed "community unionism". ${ }^{37}$ However, Martinez-Lucio and Perret challenge the stereotypical approach to black and minority ethnic union members, noting that deploying some notion of collectivity embedded within ideal constructions of "community" results in assumptions about the common interests of black and minority ethnic workers..$^{38}$ This essentialist approach tends to assess black and minority ethnic workers in terms of their deviation from the accepted norm of the white worker, though the latter are rarely burdened with assumptions about common and collective interests on account of their own community membership.

\section{Grunwick as the turning point in trade unions' representation of minority women workers?}

The management strategy at Grunwick was to continuously reduce labour costs by lowering the unit cost of production, whilst increasing the productivity of labour -what has been termed the "cheap labour" strategy. ${ }^{39}$ The recruitment strategy was to hire workers who exhibited all the classic characteristics of cheap labour - for example, labour that was readily available, that cost little or nothing to recruit, that was willing to accept low hourly and weekly wages, that offered flexibility in terms of hours, overtime and seasonal demand, and that was assumed to be docile, and therefore unlikely to resist continuous efforts to increase their productivity. According to George Ward, the joint owner of the firm, the Grunwick workforce in 1976 largely comprised migrant workers who fulfilled these desirable characteristics. ${ }^{40}$

Recruitment was by word of mouth, using the networks of existing employees. Jayaben Desai argued that the recruitment of South Asian workers was part of a deliberate strategy:

They got more work out of us. Asians had just come from Uganda and they all needed work. So they took whatever was available. Grunwick put out 'papers' [leaflets]: 'come and we will give you a job. We give jobs to everyone.' Door to door. When I went, a friend of mine followed. And soon they were full of our people.

In line with the findings of other research on migrant workers, ${ }^{41}$ the Grunwick strikers articulated their sense of themselves as "good workers" in comparison with those previously employed at Grunwick, perhaps in response to dominant negative constructions of immigrants as undeserving and "spongers", both then and now. As Jayaben Desai noted: "We never took tea breaks, did not take smoking breaks, so they got a good level of 'production'. And gradually they started shifting the workers and replaced the white workers with Asian ones."

The dispute started in the mail order and computer departments which were supervised by Malcolm Alden, one of the harsher managers according to contemporary accounts, whose responsibility was to oversee the automated system for producing invoices. He was responsible for the female Asian workers as they manually processed orders and payments for films, delivered at an increasing pace throughout the summer. Jayaben Desai recalls how the pressure of work escalated as the company expanded, a view corroborated by the Scarman Inquiry: ${ }^{42}$ 
The managers were in a glass cabinet. They could see us, and if they called us in to their office, the rest of the workers could see them, but could not hear what was going on. Such was their game plan. We used to work out of fear. model which hinged on processing customers' photos at low cost and with a rapid turnover, an important element in meeting the new consumer demand from the 1960s for instant photos from holidays in the UK and abroad. According to Levidow, the automation undertaken at Grunwick to meet this demand was "lopsided" with the chemical processing and accounting phases being subjected to an extreme automation while the clerical handing of film was undertaken by a menial, highly labour intensive routine. ${ }^{43}$ This made the clerical department the bottleneck or pressure point for keeping up with the high turnover necessary throughout the peak summer months. ${ }^{44}$ The management sought to maximise productivity in this department through constant threats of dismissal if workers did not respond to efforts to increase output, and by employing students on casual contracts during the summer. As Jayaben Desai recalled:

They had made 'rules and regulations' that you had to get permission to go to the toilets. This woman said to me that she felt ashamed to ask to go to the toilet, so she held back and was in extreme discomfort and feel a burning sensation. I told her, 'When he has no shame making you ask loudly, why should you feel ashamed?

This pressure resulted in a significant problem of labour turnover. In the mail order department, turnover was particularly high: between 1 and 20 August 1976, 32 out of 102 workers left, 27 of whom departed in the six weeks leading up to the strike. ${ }^{45}$

Compulsory overtime was also a key aspect of meeting high demand with a flexible workforce. The management typically insisted on overtime shortly before the normal end of the working day. ${ }^{46}$ This had a particularly impact on women, as it interfered with their second shift of childcare and domestic work in the evening. According to Jayaben Desai in her evidence to the Scarman Inquiry, women were also scared of going home late in the evenings. ${ }^{47}$

21 Management controls played on the gender, race and migrant status of the workers, escalating the demand for higher productivity, while seeking to reduce any control or autonomy of the workforce over the labour process. The Grunwick strikers came from households that previously had employed servants; they were used to the status and respect that accompanied their relatively privileged social status in East Africa. This fuelled their resentment at what they perceived as degrading treatment relating to use of toilets, as well as the arbitrary imposition of compulsory overtime. Their grievances were about issues other than or as well as the low pay and poor working conditions common in many small businesses during the 1970s. Although it was the issue of compulsory overtime that spurred the initial walk-out, a range of arbitrary management procedures, experienced as disrespectful and challenging their dignity as people as well as workers, were also contributory factors.

The workers who participated in the initial walk out subsequently joined the white collar trade union APEX, and their demands came to be centred on the right to union recognition and collective bargaining. After several months of local picketing, the tactic of mass picketing - developed during the miners' strike in 1972 - was vigorously deployed at Grunwick with support coming from a range of traditional unions, as well 
as from feminist and anti-racist groups, swelling the ranks of the pickets to an estimated 20,000 on a Day of Action in July 1977.

In spite of the Union of Postal Workers action to boycott mail from Grunwick - on which the firm depended to reach its client base and the recommendations of the Scarman Inquiry, ${ }^{48}$ George Ward, backed by the National Association For Freedom, (NAFF) refused to recognise the union or reinstate the sacked workers. The political climate became more hostile as an increasing unpopular Labour Government struggled for survival. The TUC and APEX retreated from mass picketing and effectively withdrew their support from the Grunwick strikers. With dwindling backing from the labour movement the frustrated strikers held a hunger strike outside the TUC headquarters in November 1977, protesting at the fact that, as Jayaben Desai, put it "Support from the TUC is like honey on your elbow: you can see it, you can smell it but you can't taste it!" In the end, the strike was abandoned on 14 July 1978, without any of the strikers' demands being met.

What began as resistance to managerial control and a protest in defence of workers' dignity and respect became transformed into a dispute about pay and union recognition. Though it ended in a defeat, the Grunwick dispute is widely celebrated as an example of labour solidarity in Britain in support of women and minority workers, and is constructed in trade union accounts as a turning point in their representation of minority and women workers.

\section{The changing context of the labour market and industrial relations regulation}

The Grunwick dispute took place at the beginning of an era characterised by the transformation from Fordist to post-Fordist methods of industrial production and a strengthening of the workers' legal rights. However, this was paralleled by the weakening of other rights which had facilitated collective bargaining, including compensation for the work of union shop stewards. ${ }^{49}$ In 1979, a newly elected Conservative Government introduced a set of measures that profoundly changed the regulatory framework in which unions operated.

Five major pieces of trade union legislation were introduced, which together served to constrict the legal space for collective action enjoyed by trade unions. Severe restrictions on the ability of unions to organise lawful industrial action were imposed, whilst also making them liable to claims for damages in the event of unlawful action. Strict controls over unions' internal governance and voting arrangements were introduced, removing all immunity in the case of secondary (solidarity) action..$^{50}$ This latter restriction was to have significant implications for the Gate Gourmet dispute in 2005.

In the decades between the two disputes, union membership declined and collective bargaining increasingly gave way to the regulation of workplace relations through the codification of statutory individual employment rights associated with the national minimum wage, parental and maternity benefits and anti-discrimination legislation ${ }^{51}$ in what Deery and Mitchell characterize as an assertion of "the primacy of the individual relationship over the collective". ${ }^{52}$ Employment Tribunals (originally named Industrial Tribunals) created by the Industrial Training Act 1964 were originally intended to 
strengthen workers' statutory individual rights and received just over 40,000 claims in 1978-9, ${ }^{53}$ the year in which the Grunwick strike ended. The number of claims made to Employment Tribunals rose across the decades, reaching over 130,000 in 2005-6, the year the Gate Gourmet dispute began, and 236,100 in $2009-10,{ }^{54}$ only to decline subsequently as upfront fees were imposed on workers taking on cases against their employer.

According to Colling, there is a link between the decline in unionisation and the rise in individual claims at Employment Tribunals, reflecting the government's view that "the definition of union services should focus on those services received by union members as individuals". ${ }^{55} \mathrm{~A}$ range of observers consider that collective bargaining has been marginalised as trade unions have been recast as providers of services and advice for individual workers, including redress through recourse to employment tribunals. ${ }^{56}$ Novitz (2002:1) argues that the unions' role has been reduced to one that is "essentially individualistic in character, procedural in form, and unitary in specification", ${ }^{57}$ although Bagguley insists that these changes represent merely a change in the "repertoire of contention" and that the pursuit of individual cases to achieve economistic class interests is still largely dependent on collective actors such as unions. ${ }^{58}$

Alongside these regulatory changes, subsequent flows of migration have led to the incorporation of new categories of workers into the lowest rungs of the labour market in a context where globalisation and outsourcing have led to the re-composition of " disposable labour". ${ }^{59}$ Inevitably these shifts have had a profound impact not only on the nature of industrial activism, but also on the role of trade unions in recruiting and supporting their members.

\section{The Gate Gourmet dispute}

The Gate Gourmet dispute took place in the wake of these changes and so followed a different trajectory from the Grunwick strike 30 years earlier. Many of the South Asian women employees of Gate Gourmet were part of the slow incorporation of minority ethnic women into trade unions, and were members of TGWU at the time of the dispute in 2005. Following BA's outsourcing of in-flight meals in 1997 and the subsequent loss of a Virgin Atlantic contract by Gate Gourmet in March 2005, the union had been attempting, with little success, to moderate the cost-cutting changes in pay and conditions imposed by the management. In this context, arbitrary management practices, including control and harassment in relation to women's use of the toilets, discussed in relation to the Grunwick strike, were also mentioned by Gate Gourmet workers:

They even began to time you when you went to the toilet. I had just come back from the toilet one day when the manager sent for me. There were 4-5 managers sitting there. He began questioning me again and again, 'What were you doing there?' I asked back, 'Why do people go to the bathroom?' He would not stop. The same question, again and again. So I lost all caution, I thought, this shameless man, let me give him such an answer that he feels shame himself. I said, 'I went to change my pad!' He was quiet. What else could he say? I had said it aloud, and he felt shame. He just sent me back to the belt. After that he would pick on me for everything. (Sukhwant, a sacked Gate Gourmet worker)

There is considerable evidence from other research on women workers in a range of production situations - manufacturing, assembly, horticulture ${ }^{60}$ - that managerial 
control over women's access to toilets is a frequent gendered strategy that is rarely deployed with male workers who have more autonomy over their physical mobility as well as different biologically-based needs. It is not possible to ascertain from the few contemporary ethnographies of women workers in the UK whether this is a generalised practice across UK industry and/or whether it is a strategy that is more usually found when workers are women of migrant origin. Both the Grunwick and the Gate Gourmet workers felt humiliated by it.

31 Management attempts to introduce new working practices aimed at speeding up the through-put of meal packs through the assembly process met with sustained resistance from the exclusively female and predominantly South Asian workers in this section:

It [work to rule] happened three times in six months. First time was when they said they did not want to give us 15 minutes to change and report for work - they said we would have to do all that in our own time. [...] So those who had put down their names for overtime withdrew their names and it went on like this for three days. The floor manager - he had been on his holidays at that time - he flew back straight on a Sunday and landed on the shop floor! ... He backtracked and said, 'If you need the 15 minutes to change, that's OK by me. Please don't delay the Concorde, I will lose thousands of pounds'. (Satvinder, a sacked Gate Gourmet worker)

32 Such mechanisms of collective resistance and bargaining are part of the general repertoire of action available to trade union members, and are not new. The women workers who were informally accepted as "leaders" frequently initiated such action at Gate Gourmet and received the backing of other women in their unit, often bypassing the shop stewards, the majority of whom were men. It was in the context of a history of shop floor resistance to continual attempts by management to introduce nonnegotiated cost reducing measures that the Gate Gourmet dispute unfolded. ${ }^{61}$

On the morning of the $10^{\text {th }}$ August 2005, the installation of agency workers on the assembly line during the tea break was seen by the workers as a deliberate provocation by the management. Some 200 workers, a majority of whom were women from the tray-set department, left their work station and assembled in the canteen to discuss this development in the presence of at least one of their shop stewards - an action which had been deployed many times in the past. They were soon joined by the union convener, Mr Dhillon. When the management issued a verbal warning through a loudspeaker, asking the workers to return to work or face dismissal, the shop stewards demanded that the management rescind the warning before the workers would resume work. After three warnings, the workers were sacked by megaphone and, when they refused to return their ID cards, they were detained for six hours in the canteen by security guards. About 700 workers were dismissed that week, and subsequent dismissals took the total number of sacked workers to 813 .

The TGWU's initial position was that the women were provoked, which is why the union initially supported the walk-out. However, according to the prevailing legislation this constituted unballoted action and so the union did not use the term "strike". The workers were not given "strike pay" but instead received payments of £50 per week from the union "hardship fund". Union officials were aware that they had to acknowledge this as unballoted action under S.26 of the Trade Union and Labour Relations (Consolidation) Act 1992 (as amended) to protect themselves against any claims for damages. However, this effectively meant ignoring the alleged role of their own shop stewards in advising the workers against returning to the shop floor, despite management warnings of dismissal. The issue of whether action by shop stewards 
constitutes direct representation of union policy or mandate is contested..$^{62}$ This posed a problem for the TGWU not just in relation to the Gate Gourmet shop stewards, but also in relation to the solidarity actions of other workers at Heathrow, who were also TGWU members. BA baggage handlers, bus drivers and ground staff staged solidarity strike action on August 10 2005, paralysing flights for 48 hours and costing BA about $£ 42$ million. The response of the TGWU president was to assert the illegality of secondary action, at the same time representing the walk-out as an expression of community support rather than workers' solidarity: "The law did not allow for these women's husbands, sons, neighbours and friends to come to their aid." ${ }^{33}$ By constructing the secondary strike action as personalised, depoliticised support for sacked family members and friends rather than as an act of class solidarity based on their common interests as workers ${ }^{64}$ Woodley was reaching for the all too familiar stereotypes that construct black and minority ethnic workers' industrial action as exotic, as communitybased and somehow different from the norms and practices of mainstream trade union members. ${ }^{65}$ Twelve months later, The Guardian revealed that the TGWU had made payments totalling $£ 600,000$ to the two shop stewards involved in the secondary action to compensate them for losing their jobs. In turn the two men agreed not to talk publicly in the face of allegations that they were following union orders by organising the secondary strike. ${ }^{66}$

Having initially supported the women, the union's position changed rapidly. Three weeks into the dispute, the TGWU announced that a Compromise Agreement had been negotiated with the management. ${ }^{67}$ The terms of this agreement included: reengagement for some select workers on worse terms and conditions and compulsory or voluntary redundancy for the remaining workers who would be offered statutory redundancy payment. Subsequently, a meeting of the sacked workers and their union representatives was organised to discuss the Compromise Agreement. 56 workers eventually refused to sign it.

According to the women workers we interviewed, at that meeting the TGWU officials recommended that all workers accept the agreement negotiated by their union. Without being given the opportunity to read the full text of the agreement, those present were asked to indicate their acceptance by a show of hands. Many of our interviewees reported that there were no interpreters present and that they were not fully informed about the terms of the agreement: "They did not read out the deal to us, they just showed us the papers, just like that [waves an imaginary sheet in the air]." (Lata, a sacked worker).

The circumstances in which the workers' agreement was secured has subsequently been questioned by some members of the TGWU Executive Council, one of whom spoke to us, although requesting anonymity: "We [The Executive Council] were told it [the Compromise Agreement] was going to be taken to the workers, that they would have to agree. I couldn't believe it when I heard, I mean 'What, didn't you actually vote on it?'." The union leadership has consistently refused to engage with any criticism of their role and has continued to put the blame for negative outcomes from the dispute firmly on the shoulders of the workers.

More than 700 sacked workers subsequently took their case for unfair dismissal to an Employment Tribunal. Since their union had not officially authorised the walk-out, the Tribunal dismissed their claim on the grounds that it was their "own choice" not to return to work. However, the written judgement corroborates the women's accounts, 
stating that Mr Dhillon (the shop steward) "followed the advice given to him by $\mathrm{Mr}$ (Brendan) Gold the National secretary (of the TGWU) which was to seek a withdrawal of the threat of dismissal before the staff returned to work" ${ }^{68}$ The judgement went further:

What none of the tribunal could understand is why having heard how the respondent (Gate Gourmet) viewed this congregation of employees Mr Dhillon (the convenor) did not address the entire group to advise them that ... they should return to work. Had he done so none of these problems would be before this tribunal. ${ }^{69}$

As a result of this union-sanctioned agreement Gate Gourmet was allowed to select for redundancy those workers who had been active members of their union and hence deemed to be "radical", ${ }^{70}$ as well as other "undesirable" less productive workers, including those who had health issues and/or were older. Drawing upon information from Gate Gourmet's own website, Hendy and Gall note that of the 813 workers who were sacked, 272 were reinstated on worse terms, 411 given the equivalent of (statutory) redundancy pay, while 130 received neither employment nor compensation. Gate Gourmet was able to shed 541 workers' jobs "by paying the equivalent of redundancy to 411". ${ }^{71}$ Additionally, the changes to workers' contracts, including reduced annual leave and sick leave, enabled Gate Gourmet to increase productivity and reduce the rights of long-standing employees to labour protection.

\section{Conclusions}

In spite of the way in which the British trade union movement has constructed the now historic Grunwick strike as an emblematic turning point in its representation of black and minority ethnic and women workers, trade unions' structures, procedures and legal frameworks have arguably not delivered any genuinely held aspirations to serve minority women effectively.

41 Since Grunwick, the trade unions in the UK have adopted a variety of strategies and frameworks to address issues of diversity. ${ }^{72}$ However, it has been argued that union strategies for mobilising and representing black and minority ethnic workers have focused on recruitment and campaigning issues. ${ }^{73}$ The underlying assumption has been that minority ethnic and women workers lack a propensity to unionise, which has precluded any radical re-examination of trade union structures and practices that might serve to exclude particular interests. On the whole, trade union approaches to gender have been more effective than to issues of race/racism. Additionally, issues raised by multiple forms of inequalities experienced by intersectional location of black and minority ethnic women workers remain largely unrecognised as race and gender have tended to be examined in discrete ways and initiatives have remained piecemeal and fragmented.

At Grunwick and Gate Gourmet, changes in the labour process combined with different elements of the women workers' experience and identity and propelled them into collective action against their employees. The issues of dignity and fairness were central to both the disputes. The Grunwick dispute was a spontaneous act of resistance to managerial control while the underlying grievances behind the Gate Gourmet dispute were downward pressures on pay and conditions and the growing use of agency and contract labour. ${ }^{74}$ The workers involved in both the disputes resorted to collective action as the result of cumulative experience of injustice based in large part on the 
discordance between their perceptions of themselves in terms of their identities as women and as workers and formed as much by their experience of migration and their class dislocation, as by any overt racist or discriminatory practices. A useful framework for understanding their position is offered by feminist analyses of intersectionality, which stress the significance of interlinking different aspects of identities. As both the disputes indicate, resistance comes not just from the experience on the production line; it is also the result of the intersection of a range of factors embodied in the workers themselves-their class, ethnic and gendered identities and their experiences of migration, all of which intersect and contribute to their perception of injustice and the need for collective action to restore their sense of worth and dignity that has been affronted by unjust treatment in the workplace. Both these disputes were about recognition as well as rights.

This dimension of industrial relations echoes Nancy Fraser's argument that "only by integrating recognition and redistribution can we arrive at a framework that is adequate to the demands of our age". ${ }^{75}$ It would seem timely to apply this analysis to the structures and processes of trade unions in Britain to forge new strategies which support the legitimate aspirations and expectations of minority women workers such as the South Asian women who protested about their treatment by both the company and their union at Gate Gourmet. But this remains a formidable challenge in a period when trade unions remain constrained by both nature of labour market in an era of globalisation and restructuring and by increasing restrictions on trade unions imposed by a neoliberal state in the UK.

In 2016, sections of the British union movement collaborated in celebrating the fortieth anniversary of the Grunwick strike ${ }^{76}$ seeking to locate the historic struggles of the 1970s within the current context of the "gig economy" characterised by the quasi selfemployment status of those working for technology-enabled companies such as Uber (taxis) and Deliveroo (meal deliveries). In spite of some significant legal victories, these burgeoning service sectors which employ large numbers of migrant workers remain largely unorganised. The trade union movement is currently exhibiting greater awareness of the need to represent and defend these new segments of the working class, but, like the food preparation workers of Gate Gourmet, there has been little significant progress in changing the conditions faced by the majority of these workers.

As the trade union movement in the UK celebrated the fortieth anniversary of the Grunwick strike, it became clear, however, that the legacy of this dispute has not been a wholehearted welcome by the labour movement of migrant workers. The events at Gate Gourmet indicate that championing the rights of migrant women workers has not been the main priority of all trade unions in the twenty first century. Not only the changing labour market referred to in this article, but also the austerity policies imposed by Conservative Governments in the post-2008 financial crisis have in part underlined the subsequent growth of anti-migrant sentiment across broad sections of the working class in the UK, manifest in the vote to leave the EU in June 2016. However, there are also indications that broad sections of the progressive left, including the leadership of the TUC are forging new alliances which have within them the possibilities of remodelling union organisation and practice to more effectively embrace the priorities of migrant and women workers in the UK. experiences of South Asian women in the UK, and on violence against women and 
girls in the UK and India. Following her research on the Grunwick and Gate Gourmet disputes, she worked with Ruth Pearson to produce educational resources for young people, including a comic on life stories of two South Asian women workers, available at: www.striking-women.org. She has previously managed a Women's Aid refuge and worked as an Advice Worker for Asha Projects, a specialist refuge, and has been active in campaigns and policy-making to address violence against women since 1999. She has just published, with Ruth Pearson, Striking women: South Asian women workers' struggles in the UK labour market from Grunwick to Gate Gourmet.

Ruth Pearson is a feminist economist who has researched and written widely on women, work, migration, development and globalisation. She is also an activist and trustee of a number of women's organisations in the UK and internationally. She is the co-author of the classical article on women workers in export production : "Nimble Fingers make Cheap workers". More recent books and articles include Thailand's Hidden Workforce: Burmese Migrant Women Factory Workers; Globalization, Export-Orientated Employment and Social Policy: Gendered Connections; Women and Credit: Researching the Past, Refiguring the Future; Corporate responsibility and Labour Rights: Codes of Conduct Economy in the Global Economy; Feminist Visions of Development: Gender Analysis and Policy. She has just published, with Sundari Anitha, Striking women: South Asian women workers' struggles in the UK labour market from Grunwick to Gate Gourmet.

Linda McDowell is a feminist geographer and labour ethnographer who has written about bankers, working class men and migrant women's working lives. She currently is a Leverhulme Emeritus Fellow, looking at poverty in coastal towns in England.

\section{BIBLIOGRAPHY}

Anitha, Sundari, Pearson, Ruth and McDowell, Linda, 'Striking Lives: Multiple Narratives of South Asian Women's Employment, Identity and Protest in the UK', Ethnicities 12(6) (2012), pp. 754-775.

Anwar, Mohammad, The Myth of Return: Pakistanis in Britain (London Heinemann, 1979).

Bagguley, Paul 'The individualisation of class struggle' (undated) <http://

www.sociology.leeds.ac.uk/about/staff/bagguley.php> [14 July2016]

Bhachu, Parminder, Twice-migrants: East-African Sikh Settlers in Britain (London and New York Tavistock Publications, 1985).

Botcherby, Sue, Pakistani, Bangladeshi and Black Caribbean Women and Employment Survey: Aspirations, Experiences and Choices (Manchester, Equal Opportunities Commission, 2006).

Brah, Avtar, Cartographies of Diaspora: Contesting Identities (London, Routledge, 1996). 
Brown, William, Simon Deakin, Davis Nash and Sarah Oxenbridge, 'The Employment Contract: From Collective Procedures to Individual Rights', British Journal of Industrial Relations 38(4) (2000), pp. $611-629$.

Bruegel, Irene, 'Women as the Reserve Army of Labour: A Note on Recent British Experience', Feminist Review 3(1979), pp. 12- 23.

Buckner, Lisa Sue Yeandle and Sue Botcherby, Ethnic Minority Women and Local Labour Markets (Manchester: Equal Opportunities Commission, 2007).

Beverley Bryan, Stella Dadzie and Suzanne Scafe, The Heart of the Race: Black Women's Lives in Britain (London Virago, 1985).

Cockburn, Cynthia, Strategies for Gender Democracy (Brussels, European Commission, 1995).

Colling, Trevor, 'What Space for Unions on the Floor of Rights? Trade Unions and the Enforcement of Statutory Individual Employment Rights', Industrial Law Journal 35(2) (2006), pp. 140-160.

Crouch, Colin, 'Atavism and Innovation: Labour Legislation and Public Policy since 1979 in Historical Perspective’, Historical Studies in Industrial Relations 2 (1996), pp. 111-124.

Dale, Angela, Lindley, Joanne and Dex, Shirley, 'A Life-course Perspective on Ethnic Differences in Women's Economic Activity in Britain' European Sociological Review 22 (4): (2006), pp. 459-476.

Datta, Kavita., McIlwaine, Cathy, Evans, Yara, Herbert, Joanna, May, Jon and Wills, Jane, Work, Care and Life Among Low-paid Migrant Workers in London: Towards a Migrant Ethic of Care (London, Queen Mary, University of London, 2006).

Davis, Mary, McKenzie, Roger and Sullivan, Wilf, Working Against Racism: The Role of Trade Unions in Britain (London, TUC, 2006).

Deery, Stephen and Mitchell, Richard, 'Individualisation and union recognition in Britain in the 1990s' in Stephen Deery and Richard Mitchell (eds.), Employment Relations: Individualisation and Union Exclusion, An International Study (Sydney, Federation Press, 1999), pp. 1-16.

Dex, Shirley, Macran, Susan., Joshi, Heather and McCulloch, Andrew 'Women's Employment Transitions Around Childbearing' Oxford Bulletin of Economics and Statistics 60(1998), pp. 97-115.

Dickens, Linda. 'Individual Statutory Employment Rights since 1997: Constrained Expansion', Employee Relations 24(6) (2002), pp. 619-637.

Dickens, Linda, ‘Gender, Race and Employment Equality in Britain: Inadequate Strategies and Role of Industrial Relations Actors' Industrial Relations Journal 28(4) (1997), pp. 282-291.

Dix, Gill, Forth, John and Sisson, Keith, Conflict at Work: The Pattern of Disputes in Britain since 1980 (London, ACAS, 2008).

Dhondy, Mala, 'The Strike at Imperial Typewriters', Race Today, July, pp. 201-5.

Dromey, Jack and Taylor, Graham, Grunwick: The Workers' Story (London Lawrence and Wishart, 1978 and 2016)

Dustmann, Christian and Fabbri, Francesca, 'Immigrants in the British Labour Market' Fiscal Studies 26(4) (2005), pp. 423-470.

Elliott, Jane, Dale, Angela and Egerton, Muriel, 'The Influence of Qualifications on Women's Work Histories, Employment Status and Earnings at Age 33', European Sociological Review 17(2001), pp. 145-168. 
Elson, Diane and Pearson, Ruth, 'Nimble Fingers Make Cheap Workers: An Analysis of Women's Employment in Third World Export Manufacturing', Feminist Review 7(1981), pp. 87- 107.

Fraser, Nancy, Justice Interruptus (London Routledge, 1997).

Fryer, Peter, Staying Power: The History of Black People in Britain (London, Pluto, 1984).

Heath, Anthony and Cheung, Sin Yi, Ethnic Penalties in the Labour Market: Employers and discrimination (London, Department for Work and Pensions 2006).

Hencke, David, '£600,000 for Shop Stewards Fired Over Gate Gourmet Strike’, The Guardian, 18 September (2006).

Hendy, John and Gall, Gregor 'British Trade Union Rights Today and the Trade Union Freedom Bill' in Keith Ewing (ed.), The Right to Strike: From the Trade Disputes Act 1906 to a Trade Union Freedom Bill 2006 (Liverpool, Institute of Employment Rights, 2006), pp.247-277.

Herbert, Joanna 'Oral Histories of the Ugandan Asians in Britain: Gendered Identities in the Diaspora', Contemporary South Asia 17(1) (2009), pp. 21-32.

Jaumotte, Florence, Female Labour Force Participation: Past Trends and Main Determinants in OECD Countries (OECD Economics Department Working Papers, No. 376, Paris, OECD Publishing, 2003).

Kirton, Gill and Greene, Anne-Marie, 'The Dynamics of Positive Action in UK Trade Unions: The Case of Women and Black Members', Industrial Relations Journal 33(2) (2002), pp.157-72.

Levidow, Les 'Grunwick: The Social Contract Meets the 20th Century Sweatshop', in Les Levidow and Bob Young (eds) Science Technology and the Labour Process, Vol. 1 (London CSE Books, 1981), pp. 123-171.

Lindley, Joanne, Dale, Angela and Dex, Shirley, 'Ethnic Differences in Women's Demographic and Family Characteristics and Economic Activity Profiles 1992-2000', Labour Market Trends, April (2004), pp. 153-65.

Martinez-Lucio, Miguel and Perrett, Rob, 'The Diversity and Politics of Trade Unions' Responses to Minority Ethnic and Migrant Workers: The context of the UK' Economic and Industrial Democracy 30(3) (2009), pp. 324-347.

Martinez, Lucio and Perrett, Rob, 'Meanings and Dilemmas in Community Unionism: Trade Union Community Initiatives and Black and Minority Ethnic Groups in the United Kingdom', Work, Employment and Society 23(4) (2009), pp. 693-710.

Massey, Doreen and Meegan, Richard, The Anatomy of Job Loss: The How, Why and Where of Employment Decline (London, Methuen, 1982).

McDowell, Linda, Anitha, Sundari and Pearson, Ruth, 'Striking Similarities: Representing South Asian Women's Industrial Action in Britain', Gender, Place and Culture 19 (2) (2012) pp. 133-152.

McDowell, L, Anitha, S and Pearson, R. (2014) 'Striking Narratives: Class, Gender and Ethnicity in the ‘Great Grunwick Strike', London, UK, 1976-1978’, Women's History Review 23 (4): 754-75.

McDowell, Linda, Migrant Women's Voices: Talking About Life and Work in the UK since 1945 (London: Bloomsbury Academic, 2016).

McBride, Anne, Hebson, Gail and Holgate, Jane, 'Intersectionality: Are we Taking Enough Notice in the Field of Work and Employment Relations?', Work, Employment \& Society 29(2) (2015), pp. 331-341.

Miller, Kenneth and Steele, Mairi, 'Employment Legislation: Thatcher and After', Industrial Relations Journal 24(3) (1993), pp. 224-235. 
Milner, Mark, 'Gate Gourmet Chief Refuses to Take Back 'Militants', The Guardian, 1 September (2005).

Ministry of Justice Employment Tribunal and EAT Statistics 2009-10 (GB) (London, Tribunal service, Ministry of Justice, 2010).

Minutes of Proceedings of the Court of Enquiry on 5 July 1977, from the Shorthand Notes of W.B. Gurney \& Sons (photocopy from the Warwick University Contemporary Records Centre).

Mirza, Heidi Safia (ed.) Black British Feminism: A Reader (London, Routledge, 1997).

Novitz, Tonia, 'A Revised Role for Trade Unions as Designed by New Labour: The Representation Pyramid and 'Partnership", Journal of Law and Society 29(2002), pp. 487-509.

ONS, Employment Patterns (London, Office for National Statistics, 2004).

Parker, Jane, 'Women's Groups in British Trade Unions', British Journal of Industrial Relations 40(2002), pp.23-48.

Parmar, Pratibha, 'Gender, Race and Class: Asian Women in Resistance', in The University of Birmingham Centre for Contemporary Cultural Studies (ed.), The Empire Strikes Back: Race and Racism in 70s Britain (London: Hutchinson \& Co., 1982), pp. 236-76.

Parreñas, Rhacel Salazar, Servants of Globalisation: Women, Migration and Domestic Work (Stanford, Stanford University Press, 2001).

Pearson, Ruth and Seyfang, Gill, “'I'll Tell You What I Want ... ": Women Workers and Codes of Conduct', in Rees Jenkins, Ruth Pearson and Gill Seyfang (eds), Corporate Responsibility and Labour Rights: Codes of Conduct in the Global Economy (London, Earthscan, 2002), pp. 43-60.

Phizacklea, Annie and Miles, Robert, Labour and Racism (London, Routledge \& Kegan Paul, 1980). Ramdin, Ron, The Making of the Black Working Class in Britain (Aldershot, Wildwood House, 1987). Race Today, 'The Imperial Typewriters: The Continuing Story', Race Today August (1974), pp. 223-225.

Rossiter, Anne, ‘Risking Gossip and Disgrace', Spare Rib 54(1977)pp. 18-19.

Raghuram, Parvati, 'Migrant Women in Male-dominated Sectors of the Labour Market: A

Research Agenda', Population, Space and Place 14(1) (2008), pp. 43-57.

Rogaly, Joe, Grunwick (Harmondsworth, Penguin Books, 1977).

Salway, Sarah. M., 'Economic Activity Among UK Bangladeshi and Pakistani Women in the 1990s: Evidence for Continuity or Change in the Family Resources Survey', Journal of Ethnic and Migration Studies 33(5)(2007), pp. 825-847.

Scarman Report, <http://www.margaretthatcher.org/document/111943>, [Accessed 30 August 2016].

Smith, Paul and Morton, Gary, 'Nine Years of New Labour: Neoliberalism and Workers' Rights', British Journal of Industrial Relations 44 (3) (2006), pp. 401- 420.

Terry, Michael, 'Employee representation: Shop Stewards and the New Legal Framework', in Paul Edwards (ed.), Industrial Relations: Theory and Practice (Oxford, Blackwell, 1995), pp. 257-284.

TUC, Women's Pay and Employment Update: A Public/private Sector Comparison (London, Trades Union Congress, 2012).

Ward, George, Fort Grunwick (London, Temple Smith, 1977). 
Wills, Jane and Melanie Simms, 'Building Reciprocal Community Unionism in the UK', Capital and Class 82(2004), pp. 59-84.

Wills, Jane, May, Jon, Datta, Kavita, Evans, Yara, Herbert, Joanna and McIlwaine, Cathy, 'London's Migrant Division of Labour', European Journal of Urban and Regional Studies 16(3) (2009), pp. $257-$ 271.

Wilson, Amrit, Finding a Voice: Asian Women in Britain (London, Virago, 1978).

Woodley, Tony, 'Gate Gourmet and Beyond', Address to the IER Conference, London, 31 January 2007.

Wrench, John, ‘Unequal Comrades: Trade Unions, Equal Opportunity and Racism', in Richard Jenkins and John Solomos (eds), Racism and Equal Opportunity Policies in the 1980s (Cambridge, Cambridge University Press, 1987), pp. 160-186.

Wrench, John, 'Trade Union Responses to Immigrants and Inequality in Denmark and the UK: The Context of Consensus and Conflict', European Journal of Industrial Relations 10(1) (2004), pp. 7-31.

Wrench, John and Virdee, Satnam, 'Organising the Unorganised: "Race”, Poor Work and Trade Unions', in Chris Smith, Peter Ackers and Paul Smith (eds) The New Workplace and Trade Unionism: Critical Perspectives on Work and Organisation (London, Routledge, 1996), pp. 240-78.

Wright, Melissa, Disposable Women and Other Myths of Global Capitalism (London and New York, Routledge, 2006).

\section{NOTES}

1. Parminder Bhachu, Twice-migrants: East-African Sikh Settlers in Britain (London and New York, Tavistock Publications,1985).

2. Joanna Herbert, "Oral Histories of the Ugandan Asians in Britain: Gendered Identities in the Diaspora", Contemporary South Asia 17(1): 21, 2009.

3. Mohammad Anwar, The Myth of Return: Pakistanis in Britain (London, Heinemann, 1979).

4. See Jack Dromey and Graham Taylor, Grunwick: The Workers' Story (London, Lawrence and Wishart, 1978 and 2016); Les Levidow, "Grunwick: The Social Contract Meets the 20th century Sweatshop," in Les Levidow and Bob Young (eds), Science Technology and the Labour Process, Vol. 1. (London, CSE Books, 1981), pp.123-171; Joe Rogaly, Grunwick (Harmondsworth, Penguin Books, 1977); Ann Rossiter, “Risking Gossip and Disgrace”, Spare Rib 54:18,1977; Amrit Wilson, Finding a Voice: Asian Women in Britain (London, Virago, 1978).

5. A community group, Grunwick 40, has been set up by Brent Trades Council, Willesden Town Team, Brent Museum \& Archive and funded by the Heritage Lottery Fund to mark the 40th anniversary of the Grunwick strike over 2016-18.

6. Linda McDowell, Sundari Anitha, and Ruth Pearson, "Striking Narratives: Class, Gender and Ethnicity in the 'Great Grunwick Strike', London, UK, 1976-1978”, Women's History Review 23(4): 754-75, 2014.

7. Linda McDowell, Sundari Anitha and Ruth Pearson, "Striking Similarities: Representing South Asian Women's Industrial Action in Britain", Gender, Place and Culture 19(2):133-152, 2012.

8. Florence Jaumotte, Female Labour Force Participation: Past Trends and Main Determinants in OECD Countries, OECD Economics Department Working Papers No. 376, (Paris, OECD Publishing, 2003). 
9. TUC, Women's Pay and Employment Update: A Public/private Sector Comparison (London, Trades Union Congress, 2012).

10. Shirley Dex, Susan Macran, Heather Joshi, and Andrew McCulloch, "Women's Employment Transitions Around Childbearing" Oxford Bulletin of Economics and Statistics 60:97-115, 1998; Jane Elliot, Angela Dale and Muriel Egerton, "The Influence of Qualifications on Women's Work Histories, Employment Status and Earnings at Age 33", European Sociological Review 17:145-168, 2001.

11. Angela Dale, Joanne Lindley, and Shirley Dex, "A Life-course Perspective on Ethnic Differences in Women's Economic Activity in Britain”, European Sociological Review 22(4): 459-476, 2006.

12. Sue doi:10.1093/indlaw/dwl011 Botcherby, Pakistani, Bangladeshi and Black Caribbean Women and Employment Survey: Aspirations, Experiences and Choices (Manchester, Equal Opportunities Commission, 2006); Lisa Buckner, Sue Yeandle and Sue Botcherby, Ethnic Minority Women and Local Labour Markets (Manchester, Equal Opportunities Commission; 2007) ; Joanne Lindley, Angela Dale and Shirley Dex, “Ethnic Differences in Women's Demographic and Family Characteristics and Economic Activity Profiles 1992-2000", Labour Market Trends, April:153-65, 2004.

13. Christian Dustmann and Francesca Fabbri, "Immigrants in the British Labour Market", Fiscal Studies 26(4):423-470, 2005.

14. Anthony Heath and Sin Yi Cheung, Ethnic Penalties in the Labour Market: Employers and Discrimination (London, Department for Work and Pensions, 2006).

15. ONS, Employment Patterns (London, Office for National Statistics, 2004).

16. Avtar Brah, Cartographies of Diaspora: Contesting Identities (London, Routledge, 1996); Irene Bruegel, "Women as the Reserve Army of Labour: A Note on Recent British Experience", Feminist Review 3:12-23,1979; Linda McDowell, Migrant Women's Voices; Talking About Life and Work in the UK Since 1945 (London, Bloomsbury Academic, 2016).

17. Angela Dale, Joanne Lindley, and Shirley Dex, “A Life-course Perspective on Ethnic Differences in Women's Economic Activity in Britain”, European Sociological Review 22(4): 459-476, 2006; Parvati Raghuram, "Migrant Women in Male-dominated Sectors of the Labour Market: A Research Agenda", Population, Space and Place 14(1):43-57, 2008; Sarah Salway, "Economic Activity Among UK Bangladeshi and Pakistani Women in the 1990s: Evidence for Continuity or Change in the Family Resources Survey", Journal of Ethnic and Migration Studies 33(5):825-847, 2007.

18. Beverley Bryan, Stella Dadzie and Suzanne Scafe, The Heart of the Race: Black Women's Lives in Britain (London, Virago,1985); Heidi Safia Mirza, Black British Feminism: A Reader (London, Routledge, 1997); Pratibha Parmar, "Gender, Race and Class: Asian Women in Resistance", in The University of Birmingham Centre for Contemporary Cultural Studies (ed.), The Empire Strikes Back: Race and Racism in 70s Britain (London, Hutchinson \& Co., 1992), pp. 236-76; Amrit Wilson, Finding A Voice: Asian Women in Britain (London, Pluto Press, 1978).

19. John Wrench and Satnam Virdee, "Organising the Unorganised: "Race", Poor Work and Trade Unions", in Chris Smith, Peter Ackers, and Paul Smith (eds), The New Workplace and Trade Unionism: Critical Perspectives on Work and Organisation (London, Routledge, 1996), pp. 240-78.

20. Rhacel Salazar Parrenas, Servants of Globalisation: Women, Migration and Domestic Work (Stanford, Stanford University Press, 2001). 
21. Anne McBride, Gail Hebson and Jane Holgate, "Intersectionality: Are we Taking Enough Notice in the Field of work and Employment Relations?", Work, Employment \& Society 29(2):331-341, 2015.

22. Avtar Brah, Cartographies of Diaspora: Contesting Identities (London, Routledge, 1996).

23. Sundari Anitha, Ruth Pearson and Linda McDowell, "Striking Lives: Multiple Narratives of South Asian Women's Employment, Identity and Protest in the UK", Ethnicities 12(6):754-775, 2012.

24. John Wrench, "Unequal Comrades: Trade Unions, Equal Opportunity and Racism", in Richard Jenkins and John Solomos (eds), Racism and Equal Opportunity Policies in the 1980s (Cambridge, Cambridge University Press, 1987), pp. 160-186.

25. Peter Fryer, Staying Power: The History of Black People in Britain (London, Pluto, 1984); Ron Ramdin, The Making of the Black Working Class in Britain (Aldershot, Wildwood House, 1987).

26. Annie Phizacklea and Robert Miles, Labour and Racism (London Routledge \& Kegan Paul, 1980); John Wrench, "Trade Union Responses to Immigrants and Inequality in Denmark and the UK: The Context of Consensus and Conflict", European Journal of Industrial Relations 10(1):7-31, 2004.

27. Linda Dickens, Gender, Race and Employment Equality in Britain: Inadequate Strategies and Role of Industrial Relations Actors", Industrial Relations Journal 28(4): 282-291, 1997; John Wrench and Satnam Virdee, "Organising the Unorganised: "Race", Poor Work and Trade Unions", in Chris Smith, Peter Ackers, and Paul Smith (eds), The New Workplace and Trade Unionism: Critical Perspectives on Work and Organisation (London, Routledge, 1996), pp. 240-78.

28. Annie Phizacklea and Robert Miles, Labour and Racism (London Routledge \& Kegan Paul, 1980); John Wrench, "Unequal Comrades: Trade Unions, Equal Opportunity and Racism", in Richard Jenkins and John Solomos (eds), Racism and Equal Opportunity Policies in the 1980s (Cambridge, Cambridge University Press, 1987), pp. 160-186.

29. Cynthia Cockburn, Strategies for Gender Democracy (Brussels, European Commission, 1995); Linda Dickens, "Gender, Race and Employment Equality in Britain: Inadequate Strategies and Role of Industrial Relations Actors", Industrial Relations Journal 28(4): 282-291, 1997; Gill Kirton and Anne-Marie Greene, "The Dynamics of Positive Action in UK Trade Unions: The Case of Women and Black Members", Industrial Relations Journal 33(2):157-72, 2002.

30. John Wrench, "Unequal Comrades: Trade Unions, Equal Opportunity and Racism", in Richard Jenkins and John Solomos (eds), Racism and Equal Opportunity Policies in the 1980s (Cambridge, Cambridge University Press, 1987), pp. 160-186.

31. Mala Dhondy, “The Strike at Imperial Typewriters", Race Today July:201-5, 1974; Race Today, "The Imperial Typewriters: The Continuing Story", Race Today August: 223-225, 1974.

32. Fiona Colgan and Sue Ledwith, "Feminism, Diversity, Identities and Strategies of Women Trade Union Activists" Gender, Work and Organization 7(4):242-57, 2000; Jane Parker, "Women's Groups in British Trade Unions", British Journal of Industrial Relations 40:23-48, 2002. 
33. John Wrench, "Trade Union Responses to Immigrants and Inequality in Denmark and the UK: The Context of Consensus and Conflict", European Journal of Industrial Relations 10(1):7-31, 2004.

34. Mary Davis, Roger McKenzie and Wilf Sullivan, Working Against Racism: The Role of Trade Unions in Britain (London, TUC, 2006).

35. Jane Wills, Jon May, Kavita Datta, Yara Evans, Joanna Herbert and Cathy McIlwaine, “London's Migrant Division of Labour" European Journal of Urban and Regional Studies 16(3): 257-271, 2009.

36. Jane Wills and Melanie Simms, "Building Reciprocal Community Unionism in the UK”, Capital and Class 82:59-84, 2004.

37. Miguel Martinez-Lucio and Rob Perrett, "Meanings and Dilemmas in Community Unionism: Trade Union Community Initiatives and Black and Minority Ethnic Groups in the United Kingdom", Work, Employment and Society 23(4):693-710, 2009.

38. Miguel Martinez-Lucio and Rob Perrett, "The Diversity and Politics of Trade Unions' Responses to Minority Ethnic and Migrant Workers: The Context of the UK", Economic and Industrial Democracy 30(3):324-347, 2009.

39. Diane Elson and Ruth Pearson, "Nimble Fingers Make Cheap Workers: An Analysis of Women's Employment in Third World Export Manufacturing”, Feminist Review 7:87107, 1981; Doreen Massey and Richard Meegan, The Anatomy of Job Loss: The How, Why and Where of Employment Decline (London, Methuen, 1982).

40. George Ward, Fort Grunwick, p. 30 (London, Temple Smith, 1977).

41. Kavita Datta, Cathy McIlwaine, Yara Evans, Joanna Herbert, Jon May, and Jane Wills, Work, Care and Life Among Low-paid Migrant Workers in London: Towards a Migrant Ethic of Care (London Queen Mary, University of London, 2006).

42. In June 1977, the Labour government set up a court of inquiry under Lord Scarman to inquire into the causes and circumstances of the Grunwick dispute and to make recommendations.

43. Les Levidow, "Grunwick: The social contract meets the 20th century sweatshop," in Les Levidow and Bob Young (eds), Science technology and the labour process, Vol. 1 (London, CSE Books, 1981), pp.123-171.

44. See Ruth Pearson, Sundari Anitha and Linda McDowell, "Striking Issues: From Labour Process to Industrial Dispute at Grunwick and Gate Gourmet", Industrial Relations Journal, 41 (5):408-428, 2010, for a detailed account of the labour process at Grunwick.

45. Joe Rogaly, Grunwick (Harmondsworth, Penguin Books, 1977).

46. Les Levidow, "Grunwick: The social contract meets the 20th century sweatshop," in Les Levidow and Bob Young (eds), Science technology and the labour process, Vol. 1 (London, CSE Books, 1981), pp.123-171.

47. Minutes of Proceedings of the Court of Enquiry on 5 July 1977, from the Shorthand Notes of W.B. Gurney \& Sons (photocopy from the Warwick University Contemporary Records Centre).

48. The Scarman Report is available at: http://www.margaretthatcher.org/document/111943 (Accessed 30 August 2016).

49. Colin Crouch, "Atavism and Innovation: Labour Legislation and Public Policy Since 1979 in Historical Perspective”, Historical Studies in Industrial Relations 2:111-124, 1996.

50. Ibid.; Kenneth Miller and Mairi Steele, "Employment Legislation: Thatcher and After", Industrial Relations Journal 24(3):224-235, 1993 
51. Linda Dickens, “Individual Statutory Employment Rights Since 1997: Constrained Expansion", Employee Relations 24(6):619-637, 2002.

52. Stephen Deery and Richard Mitchell, "Individualisation and Union Recognition in Britain in the 1990s", in Stephen Deery and Richard Mitchell (eds.) Employment Relations: Individualisation and Union Exclusion, An International Study (Sydney, Federation Press, 1999), pp. 1-16, see p. 4.

53. Gill Dix, John Forth and Keith Sisson, Conflict at Work: The Pattern of Disputes in Britain Since 1980. London, ACAS, 2008), p. 9.

54. Ministry of Justice, Employment Tribunal and EAT statistics 2009-10 (GB) (London, Tribunal Service, Ministry of Justice, 2010), p. 2.

55. Trevor Colling, "What Space for Unions on the Floor of Rights? Trade Unions and the Enforcement of Statutory Individual Employment Rights", Industrial Law Journal 35(2):140-160, 2006, see DTI 2003:40, cited in Colling 2006:143, fn 26.

56. Ibid.; William Brown, Simon Deakin, David Nash and Sarah Oxenbridge, "The Employment Contract: From Collective Procedures to Individual Rights", British Journal of Industrial Relations 38(4):611-629, 2000; Paul Smith and Gary Morton, "Nine Years of New Labour: Neoliberalism and Workers' Rights", British Journal of Industrial Relations 44 (3):401- 420, 2006

57. Tonia Novitz, “A Revised Role for Trade Unions as Designed by New Labour: The Representation Pyramid and 'Partnership'", Journal of Law and Society 29:487-509, 2002, see p.1.

58. Paul Bagguley, "The Individualisation of Class Struggle", Available at: http:// www.sociology.leeds.ac.uk/about/staff/bagguley.php (Accessed 14 July 2016).

59. Melissa Wright, Disposable Women and Other Myths of Global Capitalism (London and New York, Routledge, 2006).

60. Ruth Pearson and Gill Seyfang, “'I'll Tell You What I Want...' : Women Workers and Codes of Conduct", in Rees Jenkins, Ruth Pearson and Gill Seyfang (eds) Corporate Responsibility and Labour Rights: Codes of Conduct in the Global Economy (London, Earthscan, 2002) pp. 43-60.

61. We have put together this account of the events on $10^{\text {th }}$ August 2005 based on interviews with the sacked Gate Gourmet workers, newspaper reports and the evidence presented at the Employment Tribunal hearings.

62. Michael Terry, "Employee Representation: Shop Stewards and the New Legal Framework", in: Edwards, P. (ed.) Industrial relations: Theory and Practice pp. 257-284 (Oxford Blackwell, 1995).

63. Tony Woodley, "Gate Gourmet and Beyond", Address to the IER conference, London, $31^{\text {st }}$ January 2007.

64. Linda McDowell, Sundari Anitha and Ruth Pearson, "Striking Similarities: Representing South Asian Women's Industrial Action in Britain”, Gender, Place and Culture 19 (2):133-152, 2012.

65. Miguel Martinez-Lucio and Rob Perrett, "The Diversity and Politics of Trade Unions' Responses to Minority Ethnic and Migrant Workers: The Context of the UK", Economic and Industrial Democracy 30(3):324-347, 2009.

66. David Hencke, "£600,000 for Shop Stewards Fired Over Gate Gourmet Strike" The Guardian, 18 September 2006.

67. Details of the Compromise Agreement can be found on www.leeds.ac.uk/strikingwomen (Accessed 3 April 2017). 
68. Abbas and Others v Gate Gourmet London Ltd., paragraph 54.

69. Ibid., paragraph 75 .

70. Mark Milner, "Gate Gourmet Chief Refuses to Take Back 'Militants'” The Guardian, 1 September 2005.

71. John Hendy and Gregor Gall "British Trade Union Rights Today and the Trade Union Freedom Bill", in Keith D. Ewing (ed.), The Right to Strike: From the Trade Disputes Act 1906 to a Trade Union Freedom Bill 2006 (Liverpool, Institute of Employment Rights, 2006), pp. 247-277, see p. 249.

72. John Wrench and Satnam Virdee, "Organising the Unorganised: "Race”, Poor Work and Trade Unions", in Chris Smith, Peter Ackers, and Paul Smith (eds), The New Workplace and Trade Unionism: Critical Perspectives on Work and Organisation (London, Routledge, 1996), pp. 240-78; John Wrench, “Trade Union Responses to Immigrants and Inequality in Denmark and the UK: The Context of Consensus and Conflict", European Journal of Industrial Relations 10(1):7-31, 2004.

73. Miguel Martinez-Lucio and Rob Perrett, “The Diversity and Politics of Trade Unions' Responses to Minority Ethnic and Migrant Workers: The Context of the UK", Economic and Industrial Democracy 30(3):324-347, 2009.

74. See Ruth Pearson, Sundari Anitha and Linda McDowell, "Striking Issues: From Labour Process to Industrial Dispute at Grunwick and Gate Gourmet", Industrial Relations Journal, 41(5):408-428, 2010.

75. Nancy Fraser, Justice Interruptus (London, Routledge, 1997), see p. 12.

76. Available at: https://grunwick40.wordpress.com (Accessed 3 April 2017).

\section{ABSTRACTS}

Through a focus on two examples of industrial militancy by South Asian women workers in the UK that took place thirty years apart - the Grunwick and Gate Gourmet disputes - this article explores the effectiveness of the trade union movement in representing minority ethnic women workers. We examine these two disputes in the context of the changing nature of the labour market and the significant shift in industrial relations legislation between the 1970s and the 2000s. We reflect on what these two disputes indicate about the extent to which the British trade union movement has changed to reflect the priorities and experience of migrant women workers in the UK over the last four decades.

À travers deux exemples de militantisme de femmes sud-asiatiques au Royaume-Uni qui eurent lieu à trente années d'intervalle - les disputes de Grunwick et Gate Gourmet - cet article s'interroge sur la capacité du mouvement syndical à représenter de manière efficace les femmes appartenant à des minorités ethniques. Nous examinons ces deux disputes dans le contexte d'un marché du travail en pleine mutation et de transformations profondes des lois régissant le droit du travail entre les années 1970 et les années 2000. Nous nous interrogeons sur ce que ces deux disputes nous disent de l'évolution du mouvement syndical, depuis quarante ans, dans sa capacité à refléter les priorités et les expériences des travailleuses migrantes au Royaume Uni. 
INDEX

Mots-clés: Grunwick, Gate Gourmet, syndicats, travailleuses migrantes, intersectionalité, néolibéralisme

Keywords: Grunwick, Gate Gourmet, trade unions, migrant women workers, intersectionality, neoliberalism

\section{AUTHORS}

SUNDARI ANITHA

University of Lincoln

RUTH PEARSON

Emeritus Professor, University of Leeds, Global Development Research Group

LINDA MCDOWELL

University of Oxford 